\title{
LAPTM5 Gene
}

National Cancer Institute

\section{Source}

National Cancer Institute. LAPTM5 Gene. NCI Thesaurus. Code C150081.

This gene is involved in hematopoietic cell differentiation and embryogenesis. 